\title{
Thiocarbohydrazides: Synthesis and Reactions
}

\author{
Mohamed A. Metwally, ${ }^{1, *}$ Mohamed E. Khalifa ${ }^{2,3}$, M. Koketsu $^{4}$ \\ ${ }^{1}$ Department of Chemistry, Faculty of Science, Mansoura University, ET-35516, Mansoura, Egypt \\ ${ }^{2}$ Department of Chemistry, Faculty of Science, Taif University, P.O.Box: 888, Taif, 21974, Kingdom of Saudi Arabia \\ ${ }^{3}$ Department of Chemical Engineering, Higher Institute of Engineering and Technology, New Dameitta, Egypt \\ ${ }^{4}$ Department of Materials Science and Technology, Faculty of Engineering, Gifu University, Gifu, Japan
}

\begin{abstract}
Thiocarbohydrazides are an important class of compounds which possess applications in many fields. The chemistry of thiocarbohydrazides has gained increased interest in both synthetic organic chemistry and biological fields and has considerable value in many useful applications such as the assessment process of the three-dimensional ultrastructure examination techniques of interphase nuclei and tissues, besides their therapeutic importance. They are also described for use as fogging agents and are considered as safe, storable, and cool-burning pyrotechnic compounds for dissemination of smoke, chemical warfare agents. On the other hand, thiocarbohydrazides are used in performing a highly selective heavy metal ion adsorbent and as complexing agents for the solvent extraction separation methods. The present review covers the literature up to date for the synthesis, reactions and applications of such compounds.
\end{abstract}

Keywords Thiocarbohydrazides, TCH-Method, Ion Determination, Complex Formation, Thiohydrazide

\section{Introduction}

Study of thiocarbohydrazide and its derivatives is of great interest due to the wide use of these compounds and their valuable reactions. J. P. Thiery (1967) invented a technique for staining of cells involved in the assessment process of the ultrastructural cytochemical reactivity by scanning electron microscopy. This technique depends on periodic acid- thiocarbohydrazide-silver proteinate compound (TCH), where coating biological specimens of soft tissues with thiocarbohydrazide technique, the individual cells are clearly defined, surface contours are uniformly coated, intercellular borders are visible, cell-surface shape is outlined, and area contours are suitable for planimetry at higher magnification ${ }^{1}$, the carbohydrate content of atrial-specific granules of muscle cells $^{2}$, intracellular glycoproteins ${ }^{3}$, ultrathin sections of Araldite-embedded atriums and ventricles were also stained in the assessment process of the ultra-structural cytochemical reactivity, renin activity, and cathepsin D activity of atriums and ventricles of the bullfrog ${ }^{4,5}$. The above technique was especially useful in the study of the roundish bodies and in the compositional and structural comparison of the siphon wall with the wound wall6. Also this method was applied for vicinal glycol group detection to the study of gastric mucosa endocrine cells e.g; cat, rabbit and mouse gastric mucosa endocrine cells ${ }^{7}$ and the surface membrane of mouse myocardial cells ${ }^{8}$.

\footnotetext{
* Corresponding author:

mamegs@mans.edu.eg (Mohamed A. Metwally)

Published online at http://journal.sapub.org/chemistry

Copyright (C) 2012 Scientific \& Academic Publishing. All Rights Reserved
}

Polysaccharides associated with the cellular surface of a Gregarine (parasitic protozoan) were studied by periodic acid-thiocarbohydrazide-Ag proteinate cytochemical characterization and biochemical analysis of an isolated ghost fraction'. Conjugation of thiocarbohydrazide with a 40,000 Dalton dextran gave thiocarboxydrazyl-dextran, which is stable for a long time and suitable for electron microscopic demonstration of lectin receptors ${ }^{10}$. An ultrastructural analysis of Malus pumila was performed by examination of the adaxial leaf cuticle by electron microscopy to determine the transcuticular movement of foliarly applied chemicals, where an aqueous solution of uranyl acetate, $\mathrm{AgNO}_{3}$, and $\mathrm{PhHgOAc}$ was applied to the cuticle surface of leaf segments floated on solutions of phosphate salts or thiocarbohydrazide (TCH) which reacted within the cuticle to form insoluble electron-opaque deposits indicative of their pathways of transcuticular movement ${ }^{11}$. Also, ultrastructural cytochemistry of complex carbohydrates in lysosomal granules of human neutrophils, rabbit heterophils, rabbit and human eosinophils and basophils, and human monocytes was performed ${ }^{12}$. The carbohydrate content of human auricular specific granules was assessed by means of the periodic acid-thiocarbohydrazide-silver proteinate technique $^{13}$. Methods for visualization of complex carbohydrates ultra- structurally were employed to study specific organelles of the rat bone marrow and peripheral blood monocyte and alveolar and peritoneal macrophages ${ }^{14-16}$. A thiocarbohydrazide-Ag-proteinate (TCH-SP) sequence was applied to thin sections of specimens that had been reacted with the high Fe diamine (HID) method for ultra- structural localization of sulfated complex carbohydrates ${ }^{17}$. Ultra- structural antibody localization of $\alpha$-macroglobulin in mem- 
brane-limited vesicles in cultured cells was performed by using post-sectioning staining with the osmium/ thiocarbohydrazide/osmium and uranyl acetate/lead citrate procedures $^{18}$. Staining the outer hair cells of the guinea pig sections with the $\mathrm{HIO}_{4}$-thiocarbohydrazide-OsO $\mathrm{O}_{4}$ (PATCO) to study the effects of fixation and processing upon the morphololgical appearance of glycogen within these cells resulted in the appearance of distinct, coarse granules in the cytoplasm of the outer hair cells ${ }^{19}$. Ultra-structure of the cell wall of Candida albicans blastospores was studied, where thin sections of $\mathrm{C}$. albicans blastospores were treated by the periodic acid-thiocarbohydrazide-silver proteinate method and the electron microscopic observations were correlated with literature data on the polysaccharide composition of C. albicans cell walls to give a model of the wall ${ }^{20}$. The $\mathrm{HIO}_{4}(\mathrm{PA}) /$ thiocarbohydrazide (TCH) / $\mathrm{Ag}$ proteinate (SP) staining method for electron microscopy of plant materials produced an intensified, finely-granular product over starch grains, walls, dictyosomes, and their secretion products ${ }^{21}$. Occurrence and biosynthesis of very long chain fatty acids and alkanes in plasmalemma enriched fractions from Saccharomyces cerevisiae was studied, where electron microscopic identification of plasmalemma is best achieved with a periodic acid/thiocarbohydrazide/Ag proteinate $\operatorname{stain}^{22}$. The ligand Os binding technique with thiocarbohydrazide is a successful alternative to evaporation or sputter coating of botanical specimens ${ }^{23}$. Studies of the chemistry of the positive contrast reaction of glycogen in Epon-thin sections with tungstophosphoric acid (TPA) treated with thicarbohydrazide were performed ${ }^{24}$. The glycogen of megakaryocytes and blood platelets was investigated in glutaraldehyde- and $\mathrm{OsO}_{4}$ - fixed tissues by the $\mathrm{HIO}_{4}$-thiocarbohydrazide- $\mathrm{Ag}$ proteinate method (PA-TCH-SP) $)^{25}$. Enzymic activities and galactomannan mobilization in germinating seeds of fenugreek (Trigonella foenum-graecum L. Leguminosae) was studied by electron microscopy using periodate- thiocarbohydrazide-silver proteinate technique ${ }^{26}$. Mature and differentiating sieve tubes were examined cytochemically in Robinia pseudoacacia, Acer pseudoplatanus, and Dianthus caryophyllus by the thiocarbohydrazide-silver proteinate method $^{27}$. The organization of the growing cell wall of $\mathrm{Pa}-$ renchyma, sieve cells, and collenchyma ${ }^{28}$ and the filamentous structures of sieve elements of Mymphoides peltata petioles contained no polysaccharide components were demonstrated by this technique ${ }^{29}$. Demonstration of cholinesterases by the formation of osmium blacks at the sites of Hatchett's brown $\left(\mathrm{Cu}_{2} \mathrm{Fe}(\mathrm{CN})_{6} \cdot 7 \mathrm{H}_{2} \mathrm{O}\right)$, which deposited at the sites of cholinesterase activity in tissues by the procedure of M. J. Karnovsky and L. Roots (1964), could be enhanced by bridging to Os through thiocarbohydrazide $(\mathrm{TCH})^{30}$.

Reaction of thiocarbohydrazide with aromatic isothiocyanates afforded thiocarbobis(thiosemicarbazides). These compounds and their $\mathrm{Cu}$ and $\mathrm{Ni}$ chelates were found to have active biological effect upon plant protection against fungi ${ }^{31}$.

Thiocarbohydrazide as aldehyde blocking agent, block transformation of human peripheral lymphocytes by galactose oxidase ${ }^{32,33} \cdot \mathrm{NaBH}_{4}$ was shown to be an effective blocking reagent of aldehyde produced by $\mathrm{HIO}_{4}$ oxidation of polysaccharides in thin sections of glutaraldehyde-Os fixed epoxy-embedded tissue prepared for thiocarbohydrazide-Ag proteinate staining in electron microscopy studies ${ }^{34}$. Aldehyde reagents in the presence of heat caused rapid degradation of apurinic acid to soluble fragments. The histochemical demonstration was carried out in case of stabilizing of apurinic by reaction with thiocarbohydrazide, where thiocarbohydrazone derivatives of apurinic acid were resistant to depolymerization during incubation in both Gomori's methenamine Ag solution and Protargol and were visualized with Ag solution ${ }^{35}$.

The thiocarbohydrazones $R R^{1} \mathrm{C}: \mathrm{NNHC}(\mathrm{S}) \mathrm{NHNC}: \mathrm{R}^{2} \mathrm{R}^{3}$ ( $R, R^{1}, R^{2}$ and $R^{3}=H$, alkyl or aryl) are fungicides for textile fabrics, where prevented the growth of Aspergillus niger and Chaetomium globsum on cotton ${ }^{36}$. Thiocarbohydrazide (TCH) besides the other sulfur-containing hydrazides such as methyldithiocarbazinate (MDTC), and thiosemicarbazide (TSC) have convulsant action, where the 3 drugs inhibited pyridoxal phosphokinase in vitro. Long-latency convulsions after MDTC are comparable to those seen after $\operatorname{TSC}^{37}$.

In the endothelial cells lining the rat splenic blood vessels, neutral carbohydrates were studied by means of combined periodic acid-thiocarbohydrazide-silver protein (PA-TCHSP) and $\alpha$-amylase digestion methods ${ }^{38}$. A variety of sialic acids contained in the rat epididymis were histochemical examined, where hydrated sections were subjected either to the lectin methods using biotinylated Limax flavus, Sambucus nigra, Sambucus sieboldiana or Maackia amurensis lectins or to the selective periodate oxidn.- phenylhydrazine-thiocarbohydrazide-silver protein-physical development technique with or without sapon ${ }^{39,40}$. Epididymides from male Sprague-Dawley rats on post-natal days 14, 21, 30, 39, 49, 56 and 70 were fixed in Bouin's fluid and embedded routinely in paraffin wax and the hydrated sections were subjected to the selective periodate oxidn.- phenylhydrazine-thiocarbohydrazide-silver protein-physical deve lopment technique with or without sapon ${ }^{41}$.

Thiocarbohydrazide showed structural reinforcement effect in the preparation of rabbit knee articular cartilage for the scanning electron microscope by enhancing the binding of osmium tetroxide to it, possibly along with that of other soluble tissue constituents ${ }^{42}$. The ontogeny of pepsinogen C-producing cells in rat fundic glands was studied, where the maturation stages of the chief cells could be traced by electron microscopy along the longitudinal axis of the rat fundic gland by double-staining with anti-pepsinogen $\mathrm{C}$ antibody and $\mathrm{HIO}_{4}$-thiocarbohydrazide-Ag proteinate ${ }^{43}$. The ontogeny of sulfated glycoconjugate-producing cells in the rat fundic gland has been also studied using HID-thiocarbohydrazide (TCH)-silver proteinate (SP)-physical development (PD) technique under electron microscopy ${ }^{44}$. Sequential secretory changes in granular tubule cells caused by the secretagogue cyclocytidine were studied at the ultrastructural level using the periodic acid-thiocarbohydrazide-silver proteinate technique (PA-TCH-SP) ${ }^{45}$. An electron microscopic analysis with specific histochemical stainings for acidic glycocon- 
jugates was carried out to examine the endothelium lining blood vessels of the rat spleen using high or low iron diamine-thiocarbohydrazide-silver protein-physical development (HID or LID-TCH-SP-PD) method, with or without prior digestion with acidic glycoconjugate-degrading enzymes, such as heparitinase, testicular hyaluronidase, chondroitinase $\mathrm{B}$ and neuraminidase ${ }^{46}$. Micro-heterogeneity of pectins and calcium distribution in the epidermal and cortical parenchyma cell walls of flax hypocotyls was determined using a combination of subtractive treatment and PATAg (periodic acid-thiocarbohydrazide-silver proteinate) staining method $^{47}$. Detection of acidic glycoconjugates in a variety of mammalian connective tissues by means of a physical development procedure into high or low iron diamine- thiocarbohydrazide-silver protein (HID or LID- TCH-SP) methods ${ }^{48}$. The cellulose synthesized in the mannan medium by Acetobacter xylinum in the presence of acetyl glucomannan was stained heavily by the periodic acid- thiocarbohydrazide-silver proteinate (PATAg) method for X-ray diffractometry and FT-IR spectroscopy determination of its crystal structure ${ }^{49}$. The presence and localization of storage polysaccharides and of polysaccharides as cell structure constituents of Paracoccidioides brasiliensis yeast-like cells and protoplasts were studied using the same technique ${ }^{50}$. Identification of two glycosylated components of Mycoplasma penetrans using transmission electron microscopy was performed by staining with periodic acid- thiocarbohydrazide silver proteinate ${ }^{51}$. Lysozyme- expressing cells in human labial salivary glands were electron-lucent and exhibited reactivity for mucus staining by the periodic acid-thiocarbohydrazide-silver proteinate (PA-TCH -SP) technique $^{52}$.

Barley chromosomes were prepared for high-resolution scanning electron microscopy SEM using a combination of enzyme maceration, treatment in acetic acid and osmium impregnation using thiocarbohydrazide. Using this technique, the three-dimensional ultrastructure of interphase nuclei and mitotic chromosomes was examined ${ }^{53}$. Pollen grains made conductive for SEM by coating in a series of osmium and thiocarbohydrazide solutions (OTOTO) show charging artifacts when nonconductive detritus (sand grains, plant fragments, etc.) is present in the immediate sample area of the SEM scanning probe ${ }^{54}$.Transmission light microscopy of structurally colored semithin cartilage sections using silver proteinate by thiocarbohydrazones staining method ${ }^{55}$ and cytochemical investigations on tunic morphogenesis in the sea peach Halocynthia papillosa (Tunicata, Ascidiacea) demonstrated by the same method ${ }^{56}$. Keratan sulfate glycosaminoglycans in murine eosinophil-specific granules were examined using high iron diamine-thiocarbohydrazide-silver proteinate physical development method (HID-TCH-SP-PD) for staining ${ }^{57}$. On the other hand, thiocarbohydrazide derivatives; isatin - thiocarbohydrazone (IsTCH) and N ethylisatin- $\beta$-thiocarbohydrazone (N-Et-IsTCH) showed antiproliferative action towards healthy human peripheral blood mononuclear cells (PBMC) and on two neoplastic cell lines $^{58}$.
A highly selective heavy metal ion adsorbent could be obtained when coconut shell activated carbon is soaked in acidic aqueous thiocarbohydrazide and contacted with an aqueous heavy metal ion, e.g. Hg (II), which is effective at a lower $\mathrm{pH}$ without leakage of thiocarbohydrazide ${ }^{59}$. Also, the S-containing triazine resin used to adsorb metals from wastewaters is prepared by reacting cyanuric chloride with thiocarbohydrazide and polyether diamine or an aminosulfonic acid or its salt in a polar nonprotic solvent which is inert to the polar solvent ${ }^{60-64}$. Thiocarbohydrazide was used as a complexing agent for the solvent extraction separation of some bivalent metalssuch as $\mathrm{Cd}$ from $\mathrm{Co}, \mathrm{Cu}$, and $\mathrm{Pb}$ and of $\mathrm{Pb}$ from $\mathrm{Ni}$ and $\mathrm{Pd}$ and $\mathrm{Cu}$ from $\mathrm{Zn}$ and $\mathrm{Hg}$ and of $\mathrm{Pb}$ from $\mathrm{Zn}$ and $\mathrm{Cd}$ using various masking agents ${ }^{65,66}$. Bis(p- sulfophenyl)thiocarbohydrazide (disodium salt, $\mathrm{Na}_{2} \mathrm{H}_{2} \mathrm{~L}$ ) was used as metallochromic indicator for determination of $\mathrm{Zn}$ by complexmetric titration ${ }^{67}$.

Thiocarbohydrazides, thiosemicarbazides and their hydrazones are described for use as fogging agents for the fogging development of unfogged direct-positive Ag halide emulsions ${ }^{68}$. The formation process of photographic images is described by processing the photographic material in the presence of thiocarbohydrazide compounds of the type $R^{1} R^{2} N N H C S N R^{5} R^{3} R^{4}\left(I ; R^{1}, R^{4}=H\right.$, saturated or olefinic aliphatic, aryl, heterocyclic, or acyl group; $\mathrm{R}^{1}$ with $\mathrm{R}^{2}$ and $\mathrm{R}^{3}$ with $\mathrm{R}^{4}$ may form a methylene group or an alkyl, aryl, or heterocyclic substituted methylene group and the substituents on the methylene group may together form a carbocyclic or heterocyclic ring; $\mathrm{R}^{5}=\mathrm{H}$ or $\mathrm{R}^{1}$ with $\mathrm{R}^{4}$ or $\mathrm{R}^{5}$ may comprise the necessary atoms to form a 5-or 6-membered heterocyclic ring) in the emulsion layer as stabilizers. Thus, Thiocarbohydrazides with aliphatic, aromatic or heterocyclic substituents have an antifoggant effect during the $1^{\text {st }}$, and exert a fogging effect during the $2^{\text {nd }}$ color development of reversal materials so that an overall exposure or chemical fogging is unnecessary ${ }^{69-71}$.

Weatherability improvers for jet-printing ink compositions and inks contain water-soluble dyes, wetting agents, water, and discoloration inhibitors selected from thioureas, thiosemicarbazides, and thiocarbohydrazides ${ }^{72}$. The sheet especially useful in ink-jet recording with a coating of a porous ink-receptive layer containing selected derivatives from thiourea, thiosemicarbazide, and thiocarbohydrazide shows good ink absorption and dye fixability and provides high-quality images showing no discoloration upon storage ${ }^{73}$. Receptor sheets with good ink absorptivity and colorant-fixing ability for the nonimpact printing comprise a porous ink-receiving layer containing iodine or iodides as quenching agents and of thiourea, thiosemicarbazide, and thiocarbohydrazide derivatives as antifading agents ${ }^{74}$.

Thiocarbohydrazide, thiosemicarbazide, ethylenebis( thiosemicarbazide) and dithiobiurea are considered as safe, storable, and cool-burning pyrotechnic compounds for dissemination of smoke, chemical warfare agents, etc. ${ }^{75}$.

\section{Synthesis}




\subsection{From Hydrazine and Carbon Disulphide}

The scale-up technology for synthesis of thiocarbohydrazide (TCH) 1 was studied, using 2-chloroethanol as catalyst, $\mathrm{CS}_{2}$ and hydrazine hydrate as starting materials. The results showed that the optimized reaction conditions were $\mathrm{CS}_{2} /$ hydrazine hydrate 1:3.1- $3.2 \mathrm{~mol}$, time 10-11 h, temperature $80^{\circ} \mathrm{C}$, and the consumption of catalyst $0.15 \mathrm{~mol} / \mathrm{CS}_{2}$ mol. It was found the turbine agitator was preferable, and the total yield of $\mathrm{TCH}$ was $>90 \%{ }^{76}$. Therefore, thiocarbohydrazide 1 was prepared by reaction of $\mathrm{N}_{2} \mathrm{H}_{4}$ with $\mathrm{CS}_{2}$ in the presence of $\mathrm{H}_{2} \mathrm{O}$ with subsequent heating to remove $\mathrm{H}_{2} \mathrm{~S}^{77,78}$.

The products present due to the decomposition of the formed intermediate hydrazine dithiocarbazinate $\mathrm{H}_{2} \mathrm{NNHCS}_{2} \mathrm{H} . \mathrm{N}_{2} \mathrm{H}_{4}$ were determmined by potentiometric titration with $0.1 \mathrm{M} \mathrm{AgNO}_{3}$ of a 0.2-0.3-g sample solution treated with $5 \mathrm{~mL} 25 \% \mathrm{NH}_{4} \mathrm{OH}$ solution and $50 \mathrm{~mL} \mathrm{H}_{2} \mathrm{O}$ using $\mathrm{S}^{-2}$ selective electrode versus calomel or $\mathrm{Ag} / \mathrm{AgCl}$ electrode ${ }^{79,80}$.

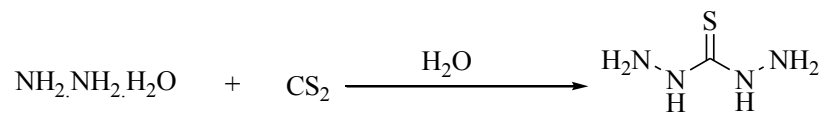

$$
\begin{aligned}
& 1
\end{aligned}
$$

\section{Reactions}

\subsection{Cyclocondensation with Cyano Derivatives}

\subsubsection{Reaction with Carbonyl Cyanide Derivatives}

Cyclocondensation of thiocarbohydrazide 1 solution in water with a mixture of acetic anhydride, sulfuric acid and tert-butylcarbonyl cyanide with stirring, afforded triazinone compound 2. Methylation of triazinone compound 2 gave herbicide metribuzin $3^{81}$.

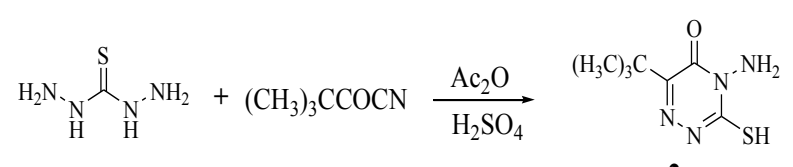

$$
\begin{aligned}
& 1 \\
& 2 \\
& \downarrow \text { Methylation } \\
& \left(\mathrm{H}_{3} \mathrm{C}\right)_{3} \mathrm{C} \overbrace{\mathrm{N}}^{\mathrm{O}} \mathrm{N}_{\mathrm{NCH}_{3}} \mathrm{NH}^{-\mathrm{NH}_{2}}
\end{aligned}
$$$$
3
$$

\subsubsection{Reaction with Dicyandiamide}

Reaction of thiosemicarbazide 1 with dicyandiamide $\mathrm{RNHC}(\mathrm{NH}) \mathrm{CN}\left(\mathrm{R}=\mathrm{H}, \mathrm{Ph}, \mathrm{p}-\mathrm{MeC}_{6} \mathrm{H}_{4}, \mathrm{p}-\mathrm{ClC}_{6} \mathrm{H}_{4}\right)$ gave 1-amino - 4-imino(or arylimino) - 6 - hydrazonohexahydro1,3,5-triazine-2-thiones 4, which were converted into 8amino (or arylamino) - 6 - hydrazono - 3 - phenyl - 4H,6H $[1,3,5]$ triazino- $[2,1-\mathrm{b}[1,3,4]$ thiadiazines 5 upon treatment with $\mathrm{PhCOCH}_{2} \mathrm{Br}$.

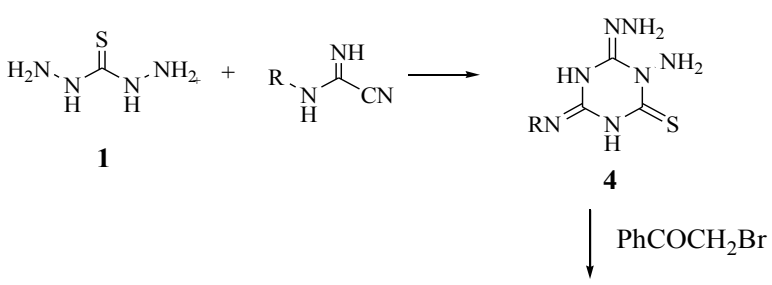

$$
\begin{aligned}
& \overbrace{\mathrm{S}}^{\mathrm{Nh}}
\end{aligned}
$$

Also, 1 reacted with $\mathrm{RNHC}(\mathrm{NH}) \mathrm{NHCN}(\mathrm{R}=\mathrm{H}, \mathrm{Ph}$, p- $\mathrm{MeC}_{6} \mathrm{H}_{4}, \mathrm{p}-\mathrm{ClC}_{6} \mathrm{H}_{4}$ ) to give 1-amino-4-imino(or arylimino) -6-iminohexahydro-1,3,5-triazine-2-thiones 6, which underwent acid hydrolysis to give 3 - amino - 5-amino(or arylamino)-1,2,4-triazoles 7, and their condensation with $\mathrm{PhCOCH}_{2} \mathrm{Br}$ gave 8 - amino(or arylamino) - 6-imino - 3 phenyl-4H,6H-[1,3,5]triazino[2,1-b][1,3,4] thiadiazines $8^{82}$.

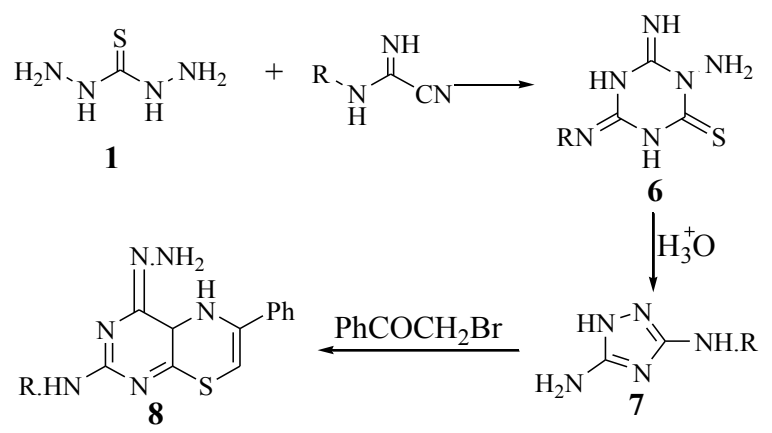

\subsubsection{Reaction with Malononitrile Derivatives}

Reaction of thiocarbohydrazide 1 with 2-(bis(methylthio) methylene)malononitrile in ethanol gave 1-(5-amino-4cyano-3-methylthiopyrazol-1-yl)carbothiohydrazide 9, which on treatment with $\mathrm{PhCO}_{2} \mathrm{H}$ and $\mathrm{POCl}_{3}$ gave 5-benzoylamino-3-methylthio-1-(5-phenyl-1,3,4-thiadiazol2-yl)pyrazole-4-carbonitrile $10^{83}$.
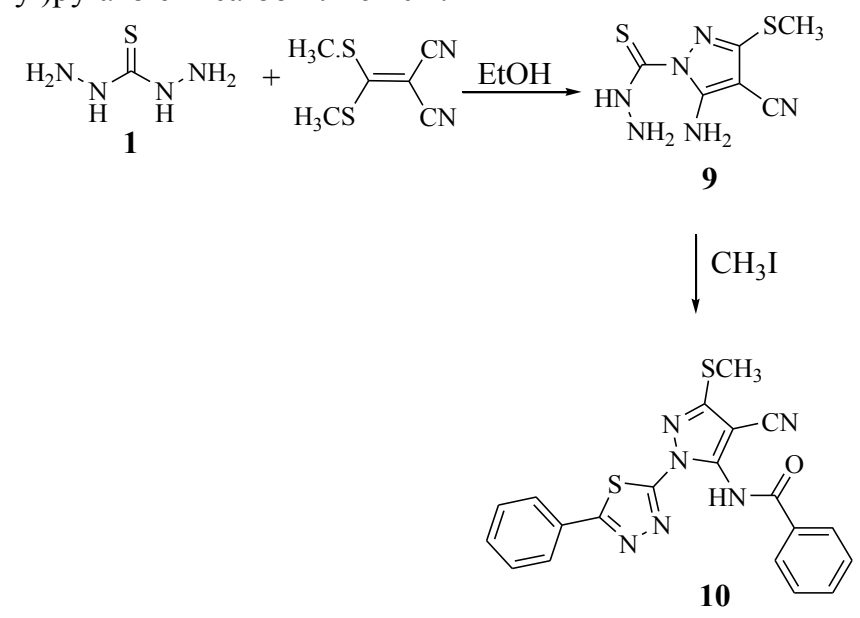

3.1.4. Reaction with Isothiocyanate Derivatives

Cyclization of thiocarbohydrazide 1 with isothiocyanate derivatives $(\mathrm{R}=$ alkyl, alkenyl, cycloalkyl, aryl) gave 
1-(3-Mercapto-4-substituted-1,2,4-triazol-5-yl)-

3-thiosemicarbazide $11^{84}$.

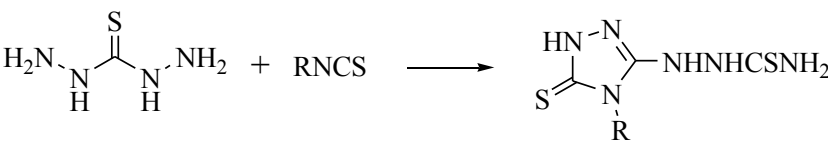

$$
\begin{aligned}
& 111
\end{aligned}
$$

\subsubsection{Reaction with Diisocyanate}

The polyaddition of thiocarbohydrazide and diisocyanate derivatives in boiling xylene-DMF mixture gave insoluble, low molecular weight thiocarbohydrazide polyurea copolymer which has good dielectric properties, but low mechanical strength and relatively low heat resistance ${ }^{85}$.

\subsection{Reaction with Amides}

Cyclocondensation of thiocarbohydrazide 1 with tertbutyl-2-(1-methylcyclopropyl)-2-oxoacetamide, followed by methylation with MeI gave 1,2,4-triazin-5-one derivative 12. At $250 \mathrm{~g} / \mathrm{ha}$ pre-emergent 12 gave $100 \%$ control of various weeds, e.g., Stellaria media. The product showed herbicidal activity ${ }^{86,87}$.

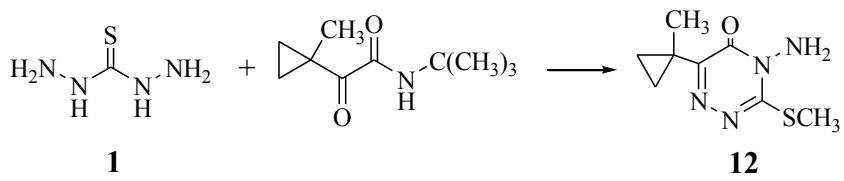

\subsection{Cyclocondensation with S-Methylated Compounds}

Cyclocondensation of thiocarbohydrazide 1 with S-methylated compounds in PhMe in pyridine gave $13^{88}$.

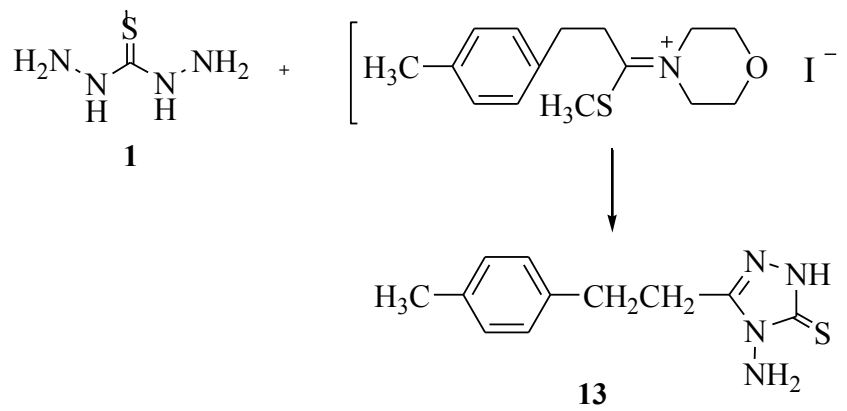

\subsection{Reaction with Acetyl Chloride Derivatives}

Thiadiazines $\left[14, \mathrm{R}=3,4-(\mathrm{HO})_{2} \mathrm{C}_{6} \mathrm{H}_{3}, 2,5-(\mathrm{HO})_{2} \mathrm{C}_{6} \mathrm{H}_{3}\right.$, 2,3,4- $\left.(\mathrm{HO})_{3} \mathrm{C}_{6} \mathrm{H}_{2}\right]$ were obtained by treatment of $\mathrm{RCOCH}_{2} \mathrm{Cl}$ with thiocarbohydrazide $1^{89,90}$.

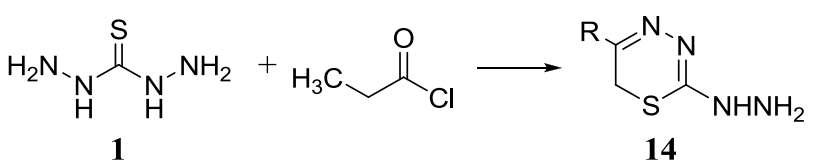

\subsection{Complex Formation Reactions}

\subsubsection{Complexation with Metal Ions}

Lanthanum(III) and praseodymium(III) complexes of thiocarbohydrazide were synthesized in the form of $\left[\mathrm{M}\left(\mathrm{L}_{1}\right) \mathrm{Cl}_{3}\right],\left[\mathrm{M}\left(\mathrm{L}_{2}\right) \mathrm{Cl}\right],\left[\mathrm{M}\left(\mathrm{L}_{3}\right) \mathrm{Cl}_{2}\right]$ and $\left[\mathrm{M}\left(\mathrm{L}_{4}\right)\right]^{91}$. Coordination polymers of $\mathrm{Cu}^{2+}, \mathrm{Ni}^{2+}$ and $\mathrm{Zn}^{2+}$ containing Schiff bases derived from thiocarbohydrazide were synthesized and characterized by elemental analalysis, IR, reflectance spectra, magnetic, DSC, TGA, x-ray diffraction and fluorescence studies $^{92} . \quad \mathrm{Cu}(\mathrm{I}), \quad \mathrm{Zn}(\mathrm{II}), \quad \mathrm{Fe}(\mathrm{II})$ complexes of 1,5-bis(acetophenone)thiocarbohydrazone were synthesized by the electrochemical oxidation of anodic metal in nonaqueous solution ${ }^{93}$. Complexes of tin(IV) and organotin(IV) chlorides with Schiff bases derived from thiocarbohydrazide as $\mathrm{Cl}_{2} \mathrm{SnL}, \mathrm{PhClSnL}$ and $\mathrm{R}_{2} \mathrm{SnL}(\mathrm{R}=\mathrm{Ph}, \mathrm{Bu}$, $\mathrm{PhCH}_{2}, \mathrm{p}-\mathrm{MeC}_{6} \mathrm{H}_{4}, \mathrm{C}_{6} \mathrm{H}_{11} ; \mathrm{L}=$ dianion of $15, \mathrm{R}^{1}=\mathrm{H}, \mathrm{Me}$ ) were prepared by the reaction of the Schiff bases with the $\mathrm{Sn}(\mathrm{IV})$ or organo-Sn(IV) chlorides ${ }^{94}$.<smiles>[R]C(=N)c1ccccc1O</smiles>

15

A study of the mode of coordination in the complexes of a number of $\mathrm{N}$ - and S-containing ligands with transition metal ions was made, based on the IR data of the shift in the thioamide bands I, II, III and IV in the ligand on complexation. The ligands are 1-substituted tetrazoline-5-thione, 3-(4-pyridyl)triazoline-5-thione and thiocarbohydrazide. Coordination through $\mathrm{N}$ and $\mathrm{S}$ of the thioamide group results in a red shift of $30-50 \mathrm{~cm}^{-1}$ in band IV, a blue shift of approximately $30-50 \mathrm{~cm}^{-1}$ in band II and reduction in intensities of band I and band III. Coordination only through S results in a red shift of approximately $40 \mathrm{~cm}^{-1}$ in band IV, no change in band I and reduction in intensities of band II and band III. Coordination only through $\mathrm{N}$ results in either no shift or blue shift of approximately $15-25 \mathrm{~cm}^{-1}$ in band IV, red shift of approximately $14-45 \mathrm{~cm}^{-1}$ in band II and reduction in intensities of band I and band III $^{95}$. Complexes of Mn(II), Ni(II), $\mathrm{Cu}(\mathrm{II}), \mathrm{Pd}(\mathrm{II}), \mathrm{Cd}(\mathrm{II})$, and $\mathrm{Pb}(\mathrm{II})$ with $1,5-$ bis (salicylidene)thiocarbohydrazide $\left(\mathrm{H}_{2} \mathrm{bstcz}\right)$ of the types $\mathrm{M}$ (bstcz). $\mathrm{nH}_{2} \mathrm{O}$ (where $\mathrm{M}=\mathrm{Mn}, \mathrm{Ni}, \mathrm{Cu}, \mathrm{Zn}$, or Pd; $\mathrm{n}=1,2$ or 3), $[\mathrm{Cu}(\mathrm{Hbstcz})(\mathrm{OAc})]_{2}$, and $\mathrm{M} 2(\mathrm{bstcz})(\mathrm{OAc})_{2} \cdot \mathrm{nH}_{2} \mathrm{O}$ (where $\mathrm{M}=\mathrm{Cd}(\mathrm{II})$ or $\mathrm{Pb}(\mathrm{II}) ; \mathrm{n}=2$ or 0 ) were prepared and characterized on the basis of analytical, spectral and magnetic moment data. The complex Ni(bstcz) $\mathrm{nH}_{2} \mathrm{O}$ was isolated in 2 forms, a 4-coordinate diamagnetic and a 6-coordinate paramagnetic form. Complexes of $\mathrm{Ni}$ (II) (diamagnetic) and $\mathrm{Pd}(\mathrm{II})$ were assigned square-planar structures, $\mathrm{Zn}$ (II) tetrahedral, $\mathrm{Cu}$ (II) distorted octahedral, and the acetato complexes of $\mathrm{Pb}(\mathrm{II})$ and $\mathrm{Cd}(\mathrm{II})$ were assigned dimeric structures $^{96}$. The Distorted octahedral complex of nickel(II) with o-hydroxy-4-benzamidothiosemicarbazide (1-salicyloyl-3-t hiocarbohydrazide) showed a magnetic moment of $2.59 \mu \mathrm{B}$, and 4 absorption bands at 9,600, 13,000, 16,000, and 31,000 
$\mathrm{cm}^{-1}$, respectively ${ }^{97}$. The IR and Raman spectra (30-4000 $\mathrm{cm}^{-1}$ ) of thiocarbohydrazide and deuterated thiocarbohydrazide were measured. Vibrational assignments were discussed by referring to characteristic group frequencies of related molecules and force constant calculations ${ }^{98}$. Also, Raman and IR spectra $\left(30-4000 \mathrm{~cm}^{-1}\right)$ of dichlorobis(thiocarbohydrazide)cadmium(II) 16 was measured where, the vibrational spectra of the Cd complex of thiocarbohydrazide were discussed in relation to that of the free ligand ${ }^{99}$.<smiles>NNC(=S)N(N)C(=S)Cl</smiles>

16

$\mathrm{ML}_{2} \mathrm{X}_{2}(\mathrm{~L}=$ thiocarbohydrazide, $\mathrm{M}=\mathrm{Zn}, \mathrm{Cd}, \mathrm{Pb}, \mathrm{Hg} ; \mathrm{X}=$ $\left.\mathrm{ClO}_{4}^{-}, \mathrm{NO}_{3}^{-}\right), \mathrm{CrL}_{2}\left(\mathrm{NO}_{3}\right)_{3}, \mathrm{PbL}\left(\mathrm{NO}_{3}\right)_{2},\left[\mathrm{MnL}_{3}\right] \mathrm{X}_{2}, \mathrm{VOQ}_{2} \mathrm{SO}_{4}$ $(\mathrm{Q}=\mathrm{L}$ and semicarbazide $)$, and $\mathrm{VOZ}_{2}\left(\mathrm{ClO}_{4}\right)_{2}(\mathrm{Z}=$ thiosemicarbazide) were prepared and characterized by magnetic properties, IR and x-ray spectra. Thiocarbohydrazide is bidentate and coordinates through the $\mathrm{S}$ atom and 1 amino group $^{100}$. $\left[\mathrm{NiL}_{3}\right]\left(\mathrm{ClO}_{4}\right)_{2} \quad(\mathrm{~L}=$ thiosemicarbazide $)$ and $\left[\mathrm{MQ}_{3}\right] \mathrm{X}_{2}\left(\mathrm{M}=\mathrm{Cu}, \mathrm{Ni}, \mathrm{X}=\mathrm{ClO}_{4}, \mathrm{NO}_{3}, \mathrm{Q}=\right.$ thiocarbohydrazide; $\mathrm{M}=\mathrm{Co}, \mathrm{X}=\mathrm{ClO}_{4}, \mathrm{NO}_{3}, \mathrm{Cl}$ ) were prepared by the reaction of the ligand with the appropriate metal salt. The diamagnetic $\mathrm{Co}(\mathrm{III})$ complexes and paramagnetic $\mathrm{Ni}(\mathrm{II})$ complexes have pseudooctahedral symmetry; the paramagnetic $\mathrm{Cu}(\mathrm{II})$ complexes have the tetragonal-distorted octahedral configuration. The ligands $\mathrm{L}$ and $\mathrm{Q}$ are bound to the metal through the $\mathrm{S}$ atom and $\mathrm{N}$ atom of the amino group ${ }^{101}$. The electronic spectrum of $\left[\mathrm{CrL}_{2}\right] \mathrm{Cl} \quad[\mathrm{HL}=4-$ (o-hydroxybenzamido)thiosemicarbazide] gave 4 bands at $13600,17420,27400$, and $34500 \mathrm{~cm}^{-1}$ from which Racah interelectronic repulsion parameters B35 and B55 were calculated, which yielded a covalency parameter $0.89^{102}$. Several mono- and bis- carbono- and thiocarbonohydrazone ligands and metal complexes of $\mathrm{Cu}(\mathrm{II}), \mathrm{Fe}(\mathrm{II})$, and $\mathrm{Zn}(\mathrm{II})$ salts were tested in vitro against Gram positive and Gram negative bacteria, yeasts and moulds. In general, the bisthiocarbonohydrazones possess the best antimicrobial properties and Gram positive bacteria are the most sensitive microorganisms $^{103}$. Cobalt(II) chloride forms a 1:1 complex with Schiff base derived from salicylaldehyde and thiocarbohydrazide. Kinetic parameters like apparent activation energy, frequency factor, activation entropy and apparent order of reaction of complex have been determined employing Freeman-Carroll, Fuoss et al., Coats-Redfern, Karkhanawala-Dharwadker and Doyle methods as modified by Zsako using non-isothermal TG curves. The complex decomposes regularly without any distinguishable rest with random nucleation mechanism ${ }^{104}$. The complexes of tin(IV) chloride with tetradentate Schiff bases $\mathrm{H}_{2} \mathrm{~L}$ derived from the 1:2 condensation of thiocarbohydrazide with benzoin, were prepared in alcoholic medium ${ }^{105}$. Sn(II) and $\mathrm{Sn}(\mathrm{IV})$ com- plexes of dibenzaldehyde thiocarbohydrazone, diacetophenone thiocarbohydrazone, dicyclohexanone thiocarbohydrazone, disalicylaldehyde thiocarbohydrazone, dicinnamaldehyde thiocarbohydrazone and di-o- hydroxyacetophenone thiocarbohydrazone were prepared as chloro and iodo heteroleptic complexes ${ }^{106}$. The $\mathrm{Cu}(\mathrm{II}), \mathrm{Ni}$ (II) and $\mathrm{Zn}$ (II) metal complexes of Schiff bases derived from thiocarbohydrazide and salicylaldehyde, o-vanillin, 2,4- dihydroxybenzaldehyde or 2-hydroxy-1-naphthaldehyde were showed fluorescence, antibacterial and pigmentation properties ${ }^{107}$. The ligand 1,5-bis(p-aminoacetophenone) thiocarbohydrazone was synthesized by condensation reaction of thiocarbohydrazide with 4'-aminoacetophenone in ethanol in the presence of acetic acid by refluxing for 4 hours. Its complexes with $\mathrm{Cu}(\mathrm{I}), \mathrm{Zn}(\mathrm{II}), \mathrm{Fe}(\mathrm{II}), \mathrm{Sn}(\mathrm{II})$, and $\mathrm{Pb}$ (II) were synthesized by electrochemical oxidation of anodic metal method with $\mathrm{Cu}, \mathrm{Zn}, \mathrm{Fe}, \mathrm{Sn}$, or $\mathrm{Pb}$ as anodes in the ligand/nonaqueous solution ${ }^{108}$.

\subsubsection{Determination of Metal ions}

Online separation and sequential determination of trace amounts of heavy metals in biological materials by flow injection inductively coupled plasma atomic emission spectrometry were conducted based on the complexation of the metal ions with 1,5-bis(di-2-pyridyl)methylene thiocarbohydrazide ${ }^{109}$.

\subsubsection{Zinc Determination}

A simple and rapid method is described for the preconcentration and determination of zinc in water using column packed with silica gel functionalized with 1,5-bis (di-2-pyridyl)methylene thiocarbohydrazide (DPTH-gel) ${ }^{110}$.

\subsubsection{Copper Determination}

$\mathrm{Cu}(1.8-15.0 \mu \mathrm{g})$ was determined spectrophotometrically at $455 \mathrm{~nm}$ (molar absorptivity was $2.06 \times 104)$ after complexation at $\mathrm{pH} 2.5$ with 1,5-diphenylthiocarbohydrazide and extraction of the complex into BuOAc. Beer's law was obeyed for 0.18-1.5 ppm Cu. Ag present in amts. equivalent to $\mathrm{Cu}$ interfered. The method was used to determine 0.735 ppm $\mathrm{Cu}$ in a 100 -g mushroom sample ${ }^{111}$.

\subsubsection{Bismuth Determination}

Reaction of di(p-sulfophenyl)thiocarbohydrazide with bismuth ions at $\mathrm{pH} 1.15$, where $\mathrm{Bi}^{3+}$ replaces 1 proton from each of 3 molecules of the dianion of $\operatorname{di}(\mathrm{p}$ - sulfo phenyl)thiocarbohydrazide to form a red complex, with maximum absorbance at $510 \mathrm{~nm}$, and a formation const. of $(3.4 \pm 1.2) \times 10^{-22}$. This reagent is a satisfactory metal indicator for use in the EDTA titration of $\mathrm{Bi}^{3+112}$.

\subsubsection{Cadmium Determination}

An FI-ICP-AES method for the determination of trace levels of cadmium in biological samples is described based on the complexation of the metal ion with 1,5 - bis(di 2-pyridyl)methylene thiocarbohydrazide (DPTH) and its 
subsequent online extraction into iso- $\mathrm{Bu} \mathrm{Me}$ ketone $(\text { IBMK })^{113}$.

\subsubsection{Cobalt Determination}

Determination of cobalt in biological samples by electrothermal atomic absorption spectrometry after extraction of the metal into $\mathrm{Me}$ iso-Bu ketone (MIBK) containing 1,5-bis(di-2-pyridylmethylene) thiocarbohydrazide ${ }^{114}$.

\subsubsection{Palladium Determination}

The use of thiocarbohydrazide as a masking agent provides rapid masking at room temperature, enabling an EDTA titration to give an indirect determination of palladium ${ }^{115}$.

\subsubsection{Mercury Determination}

Automated online separation-preconcentration system for inductively coupled plasma atomic emission spectrometry and its application to mercury determination, where the preconcentration step is performed on a chelating resin microcolumn [silica gel functionalized with 1,5 - bis(di 2-pyridyl) methylene thiocarbohydrazide] placed in the injection valve of a simple flow manifold ${ }^{116}$.

\subsection{Reaction with Organic Acids}

Cyclocondensation of thiocarbohydrazide 1 with organic acids $\mathrm{RCOOH}$ and condensation of the resulting aminotriazolethiones with ketones $\mathrm{R}^{1} \mathrm{COR}^{2}$, the (methyleneamino) triazolethiones $17\left[\mathrm{R}=\mathrm{Me}, \mathrm{Et}, \mathrm{MeCH}_{2} \mathrm{CH}_{2} ; \mathrm{R}^{1}=2\right.$-furanyl, 2-pyridinyl, $\left.\mathrm{R}^{2}=\mathrm{H}, \mathrm{Me}\right]$ were obtained ${ }^{117}$.<smiles>[R]C([R])=Nn1c([R])n[nH]c1=S</smiles>

17

The reaction of thiocarbohydrazide 1 with carboxylic acids $\mathrm{RCOOH}[\mathrm{R}=\mathrm{PhCH} 2, \mathrm{Me}, 4-\mathrm{MeC} 6 \mathrm{H} 4, \mathrm{Ph}, \mathrm{Ph}(\mathrm{CH} 2) 2$, $\mathrm{Ph}(\mathrm{CH} 2) 3, \mathrm{Me} 2 \mathrm{CHCH} 2]$ at the melting temperature allowed an improved preparation of the 5-substituted aminomercapto-1,2,4-triazoles 18, which reacted easily with carboxylic acids or carboxylic acid chlorides to afford the 1,2,4-triazolo[3,4-b][1,3,4]thiadiazoles $19(\mathrm{R} 1=\mathrm{Et}$, $\mathrm{Me} 2 \mathrm{CHCH} 2, \mathrm{Ph}, \mathrm{Me})^{118}$. These compounds did not show any significant activity ${ }^{119}$.

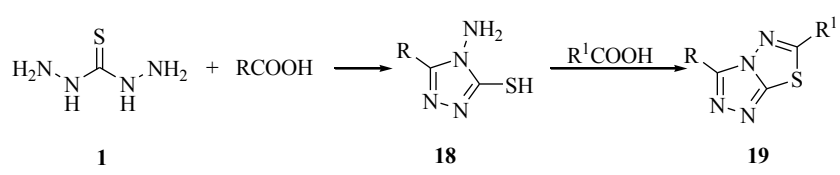

The product of thiocarbohydrazides, organic acids, and the macrocyclic compounds produced by condensation of benzil and thiocarbohydrazide, showed corrosion inhibition action, their inhibiting action on corrosion inhibition of mild steel was investigated by weight loss and potentiodynamic polarization methods ${ }^{120,121}$.
Cyclization of EtCHMeCOCO${ }_{2} \mathrm{H}$ or $\mathrm{Me}\left(\mathrm{CH}_{2}\right)_{4} \mathrm{C}(\mathrm{Z}) \mathrm{CO}_{2} \mathrm{H}$ $(\mathrm{Z}=\mathrm{O}, \mathrm{S})$ with 1 followed by treatment with $\mathrm{MeI}$ to give 6-sec-butyl-1,2,4-triazin-5(4H)-ones 20 was useful as herbicides $^{122}$.

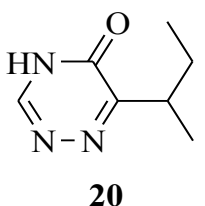

\subsubsection{Reaction with Valeric Acid}

Reaction of thiocarbohydrazide with valeric acid gave the triazole ligand, 4-amino-3-butyl-1,2,4-trizole-5-thione 21. Metal salts, $\mathrm{Co}\left(\mathrm{NO}_{3}\right)_{2} \cdot 6 \mathrm{H}_{2} \mathrm{O}, \mathrm{Ni}\left(\mathrm{NO}_{3}\right)_{2} \cdot 6 \mathrm{H}_{2} \mathrm{O}, \mathrm{Zn}\left(\mathrm{NO}_{3}\right)_{2}$. $6 \mathrm{H}_{2} \mathrm{O}$, and $\mathrm{Mn}\left(\mathrm{NO}_{3}\right)_{2} \cdot 6 \mathrm{H}_{2} \mathrm{O}$, were combined with the ligand in ethanol forming its metal complexes. The metal ions should attach to the amine and the thione groups on the triazole ligand forming a cis or trans isomer of $\left[\mathrm{M}\left(\mathrm{SN}_{4} \mathrm{C}_{6} \mathrm{H}_{12}\right)_{2}\left(\mathrm{H}_{2} \mathrm{O}\right)_{2}\right]\left(\mathrm{NO}_{3}\right)_{2}$ where $\mathrm{M}$ is $\mathrm{Co}, \mathrm{Ni}, \mathrm{Zn}$, or $\mathrm{Mn}^{123}$.

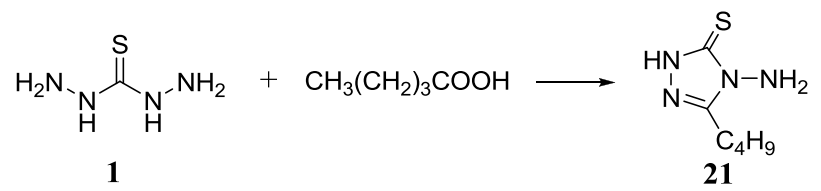

\subsubsection{Reaction with Aldonic Acids}

The reaction of thiocarbohydrazide with aldonic acids gave 3-(alditol-1-yl)-4-amino-5-mercapto-1,2,4-triazoles. Their reactions with phenacyl bromide afforded the corresponding acyclo C-nucleoside analogs 3-(alditol-1-yl) -1,2,4-triazolo[3,4-b][1,3,4]thiadiazines. Triazoles and their fused heterocyclic analogs possess significant biological activities ${ }^{124}$.

\subsubsection{Reaction with (o-formylphenoxy)Acetic Acid}

Three Schiff base ligands, bis(o-formylphenoxy)acetic acid thiocarbohydrazone, mono(o-formylphenoxy)acetic acid thiocarbohydrazone, and bis(o-formylphenoxy)acetic acid hydrazone, were prepared by condensation of (o-formylphenoxy)acetic acid with thiocarbohydrazide 1 and hydrazine hydrate ${ }^{125}$.

\subsubsection{Reaction with 3-Nitrobenzeneboronic Acid}

Reaction of thiocarbohydrazide 1 with $\mathrm{R}^{1} \mathrm{CO}_{2} \mathrm{H}$ and 3-nitrobenzeneboronic acid in the presence of an organic solvent to give $87.4 \%$ of $22\left[\mathrm{R}^{1}=\mathrm{Me}\left(\mathrm{CH}_{2}\right)_{11} \mathrm{SO}_{2}\left(\mathrm{CH}_{2}\right)_{3}\right]^{126}$.<smiles>[R]c1nnc(S)n1N</smiles>

22

3.6.5. Reaction with Arylpyruvic Acids 
Condensation of thiocarbohydrazide 1 with arylpyruvic acids $\mathrm{RC}_{6} \mathrm{H}_{4} \mathrm{CH}_{2} \mathrm{COCO}_{2} \mathrm{H}\left(\mathrm{R}=\mathrm{H}, 4-\mathrm{Cl}, 3,4-\mathrm{OCH}_{2} \mathrm{O}\right)$ in aqueous ethanol gave 4-amino-6-arylmethyl-3- mercapto-1,2,4-triazin-5(4H)-ones $23\left(\mathrm{R}^{1}=\mathrm{H}\right)$. In a modified method 23 have also been prepared by direct condensation of the intermediate azalactones 24 with thiocarbohydrazide 1 . Compound $23\left(\mathrm{R}^{1}=\mathrm{H}\right)$ on condensation with substituted benzaldehydes ArCHO $\left(\mathrm{Ar}=4-\mathrm{MeC}_{6} \mathrm{H}_{4}, 2-\mathrm{HOC}_{6} \mathrm{H}_{4}\right.$, 5-Br-2- $\mathrm{HOC}_{6} \mathrm{H}_{3}$, etc.) afford the corresponding Schiff bases $23\left(\mathrm{R}^{1}=\mathrm{CHAr}\right)$. Some of them are screened for their antifungal activities ${ }^{127}$.

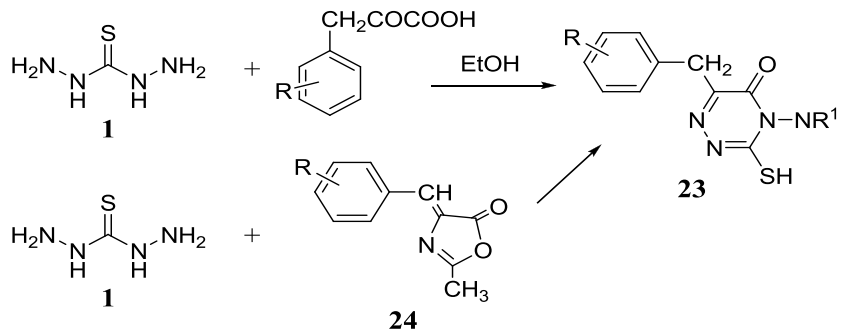

\subsubsection{Reaction with Dicarboxylic Acid}

Bis(mercaptotriazolyl)alkanes $25\left(\mathrm{R}=\mathrm{H}, \mathrm{NH}_{2} ; \mathrm{n}=1-4\right)$ were prepared in one-step from thiocarbohydrazide derivatives and dicarboxylic acid e.g., $\mathrm{HO}_{2} \mathrm{C}\left(\mathrm{CH}_{2}\right)_{\mathrm{n}} \mathrm{COOH}^{128}$.<smiles>[R]n1c(C)n[nH]c1=S</smiles>

25

\subsubsection{Reaction with Substituted Oxobutanoic Acid}

Reaction of thiocarbohydrazide 1 with 3,3-dimethyl2-oxobutanoic acid and/ or 2,2- dibromo-3,3- dimethylbutanoic acid in $\mathrm{H}_{2} \mathrm{O}-\mathrm{MeOH}$ at reflux afforded 4-amino6-tert-butyl-3-mercapto-1,2,4-triazin-5-one $26^{129,130}$.

$$
\text { (n) }
$$

While, reaction of thiosemicarbazide 1 with alkali metal salts of 3,3-dimethyl-2-oxobutyric acid, e.g. $\mathrm{Me}_{3} \mathrm{CCOCO}_{2}$ $\mathrm{Na}^{+}$formed by treating of pinacolone with $\mathrm{SCl}_{2}$ followed by $\mathrm{Me}_{2} \mathrm{NH}$ and hydrolysis, gave 6-tert-butyl-3-mercapto-4amino-1,2,4-triazin-5(4H)-one $27^{131}$.

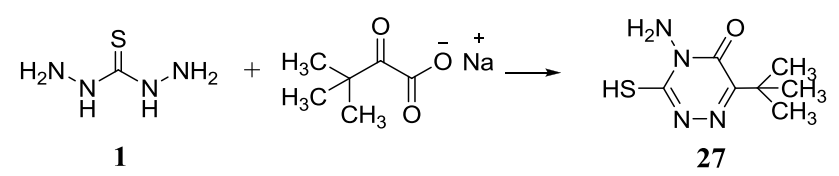

\subsubsection{Reaction with Glycine Derivatives}

Condensation of thiocarbohydrazide 1 and glycine afforded $\mathrm{N}$-(dihydrazinomethylene)glycine 28 which was assayed for reduction of hyperglycemia and obesity in mice $^{132}$<smiles>CC(N)=NCC(=O)O</smiles>

\subsection{Reaction with Esters}

Condensation of $\mathrm{NH}_{2} \mathrm{NHC}(\mathrm{SMe}): \mathrm{NNH}_{2}$. HI with the $\mathrm{RCOCH}_{2} \mathrm{CO}_{2} \mathrm{Et}$, the pyrazolotriazoles $29(\mathrm{R}=\mathrm{Ph}$, 4-, $\left.3-\mathrm{O}_{2} \mathrm{NC}_{6} \mathrm{H}_{4}, \mathrm{R}^{1}=\mathrm{SMe}\right)$ were obtained. Treatment of $29(\mathrm{R}=$ $\mathrm{Me}, \mathrm{R}^{1}=\mathrm{Ph}$ ) with 4-diethylamino-2-methylaniline, gave a range of azamethine dyes $30^{133}$.<smiles>[R]c1cc2[nH]nc([R1])n2n1</smiles>

29<smiles>CCN(CC)c1ccc(N=C2C(C)=Nn3c2nnc3-c2ccccc2)c(C)c1</smiles>

30

\subsection{Reaction with Quinoxaline Derivatives}

Condensation of thiocarbohydrazide 1 with 6-benzoyl-2,3-dichloroquinoxaline yielded triazole derivative $31^{134}$.

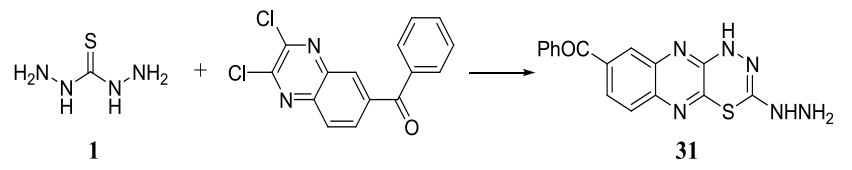

\subsection{Reaction with Coumarin Derivatives}

The interaction of thiocarbohydrazide 1 with N-4-methyl-7-hydroxy - 8 - acetocoumarin yielded N - 4 methyl-7-hydroxy-8-acetocoumarinylthiocarbohydrazide (MHACTC) 32 which is considered as ligand in nature ${ }^{135}$.

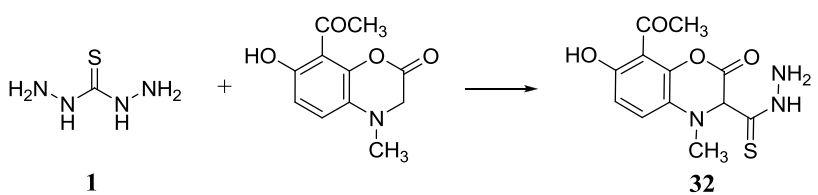

\subsection{Oxidation}

Thiocarbohydrazide 1 , in addition to thiosemicarbazide and thiourea underwent $\mathrm{Cu}^{2+}$ mediated oxidation in DMF in the presence of 2,2'-bipyridine (bpy) to produce cis$\left[\mathrm{Cu}(\right.$ bpy $\left.)\left(\mathrm{H}_{2} \mathrm{O}\right)_{2} \mathrm{SO}_{4}\right]$ which crystallized in space group triclinic P.hivin. $1^{136}$.

\subsection{Reaction with Bisisatin}

By improved Sandmeyer procedure 2,6-diaminotoluene 
was converted into the bisisatin. Refluxing bisisatin with thiocarbohydrazide 1 in acetic acid afforded the corresponding bis-Schiff bases $33\left[\mathrm{Z}=\mathrm{NNHC}(\mathrm{S}) \mathrm{NHNH}_{2}\right]$, which underwent refluxing with acetic anhydride to give $\mathrm{N}$-acetylated bis-1,3,4-thiadiazoline compound 34 in $73 \%$ yield ${ }^{137}$.

$$
\text { (n) }
$$$$
34
$$

\subsection{Reaction with Oxazinone Derivative}

Reaction of 2-phenyl-4H-3,1-benzoxazin-4-one with thiocarbohydrazide 1 in refluxing ethanol affords 2-phenyl-3 -thiosemicarbazido - $4(3 \mathrm{H})$ - quinazolinone 35. However, thioxo-tetrazinoquinazoline $36(\mathrm{R}=\mathrm{H})$ is obtained in $79 \%$ isolated yield when the reaction mixture is fused in an oil bath at $160^{\circ} \mathrm{C}$ and also obtained when 35 is heated in an oil bath at $170^{\circ} \mathrm{C}$. Compound $36(\mathrm{R}=\mathrm{H})$ reacted with paraformaldehyde and secondary amines to afford $36\left(\mathrm{R}=\mathrm{CH}_{2} \mathrm{NEt}_{2}\right.$, 1-piperidinomethyl) ${ }^{138}$.
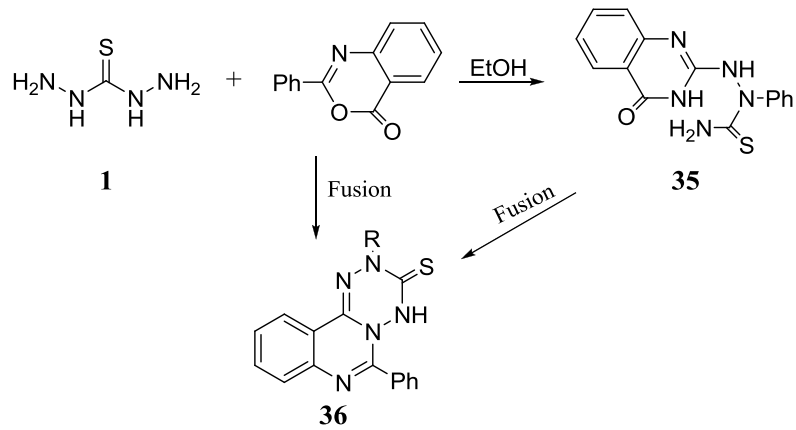

35

\subsection{Reaction with Lactones}

Reaction of D-glucono- or D-galactono-1,5-lactones and D-glycero-D-guloheptonic-1,4-lactone with thiocarbohydrazide 1 afforded the seco C-nucleosides 4-amino-3-(Dgluco- or D-galacto-pentitol-1-yl)-5-mercapto-1,2,4 - triazoles and 4-amino-3-(D-glycero-D-gulo-hexitol- 1-yl)-5mercapto-1,2,4-triazole, e.g.; reaction of di-Et galactrate with thiocarbohydrazide 1 gave 1,4-bis (4-amino-5- mercapto-1,2,4-triazol-3-yl)-galacto-tetritol, which upon reaction with acetic anhydride gave 1,4-bis(6-methyl-1,2,4triazolo[3,4-b] 1,3,4-thiadiazol-3-yl)- 1,2,3,4-tetra-O- acetyl-galacto-tetritol. When the tetra-O-acetylgalactaric acid was used instead of di-Et galactrate, the attack of thiocarbohydrazide had taken place on the ester group rather than the carboxylic group ${ }^{139}$. The synthesis of 4-amino-3-(Dgluco- or D-galacto- pentitol-1-yl)-5-mercapto-1,2,4- triazoles and their conversion to the resp. 6-methyl-3 - $(1,2,3,4,5$ - penta-O-acetyl- pentitol-1-yl)1,2,4-triazolo[3,4-b]1,3,4- thiadiazoles, e.g. 37, have been achieved. The vicinal coupling constituents were used to deduce the favoured conformations ${ }^{140}$.<smiles>COOC(OC)C(OC(C)=O)C(OC(C)=O)C(OC(C)=O)c1nnc2sc(C)nn12</smiles>

37

\subsection{Reaction with Aldehydes and Ketones}

\subsubsection{Reaction with Benzaldehyde Derivatives}

1,5-Bis(2-chloro-4-(piperazin-1-yl)benzylidene)thiocarbo nohydrazide 38 , useful as anthelmintics, was obtained by reaction of 2-chloro-4-(1-piperazinyl)benzaldehyde with thiocarbohydrazide $1^{141}$.

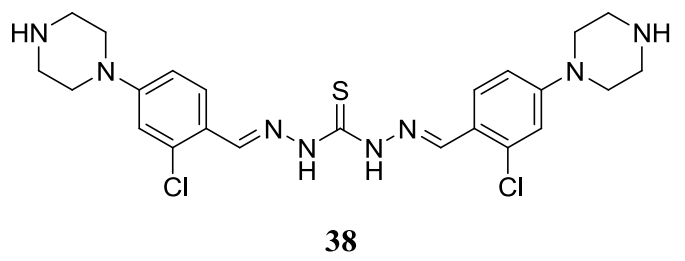

\subsubsection{Reaction with Dialdehydes}

Cyclocondensation of thiocarbohydrazide 1 with dialdehydes $(\mathrm{n}=1,2)$ in the presence of $\mathrm{Al}$ or $\mathrm{Ga}$ ions afforded macroheterocycles containing thiocarbohydrazone fragments $39(\mathrm{n}=1,2)^{142}$.

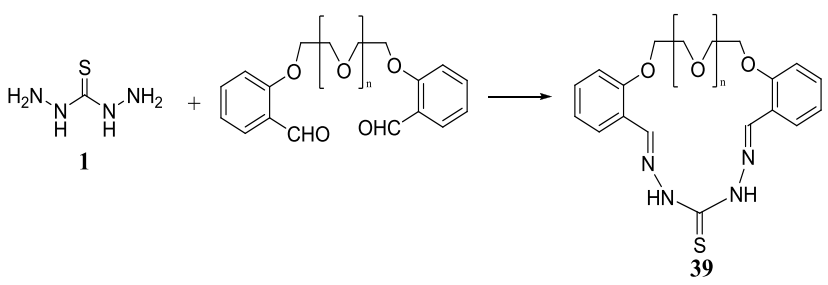

\subsubsection{Reaction with Hydroxybenzaldehyde}

Reaction of thiocarbohydrazide 1 with 2-hydroxybenzaldehyde gave 1,5 -bis(2-hydroxybenzaldehyde) dithiocarbohydrazone $40^{143}$.<smiles>Oc1ccccc1/C=N/NC(=S)N/N=C/c1ccccc1O</smiles>

40

3.14.4. Reaction with Ketones 
Reaction of thiocarbohydrazide 1 with methylhexyl ketone $\mathrm{Me}\left(\mathrm{CH}_{2}\right)_{5} \mathrm{COMe}$ yielded $71.5 \% \quad \mathrm{Me}\left(\mathrm{CH}_{2}\right)_{5} \mathrm{CMe}$ : $\mathrm{NNHCSNHNH}_{2} 41$ in refluxing aqueous alcohol, while 1 condensed with $m-\mathrm{O}_{2} \mathrm{NC}_{6} \mathrm{H}_{4} \mathrm{CHO}$ in refluxing aqueous alcohol to form $98 \%\left(m-\mathrm{O}_{2} \mathrm{NC}_{6} \mathrm{H}_{4} \mathrm{CH}: \mathrm{NNH}\right)_{2} \mathrm{CS} 42^{144}$.

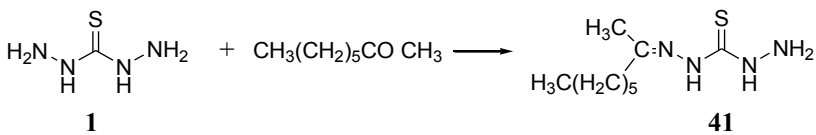

$$
\begin{aligned}
& \longrightarrow
\end{aligned}
$$

Reaction of thiocarbohydrazide 1 with hexane-2,5-dione gave pyrrole derivatives $43\left[\mathrm{R}=2-\mathrm{MeC}_{6} \mathrm{H}_{4}, \mathrm{MeO}\left(\mathrm{CH}_{2}\right)_{3}\right.$, $\mathrm{PrO}\left(\mathrm{CH}_{2}\right)_{2}, 4-\mathrm{ClC}_{6} \mathrm{H}_{4}, 4-\mathrm{BrC}_{6} \mathrm{H}_{4}, \mathrm{Ph}, 2,5-(\mathrm{MeO}) \mathrm{MeC}_{6} \mathrm{H}$, 2,6- $\mathrm{Me}_{2} \mathrm{C}_{6} \mathrm{H}_{3}, 4-\mathrm{H}_{2} \mathrm{NC}_{6} \mathrm{H}_{4}$, 4-AcNHC $\left.\mathrm{H}_{4}\right]$. The products synthesized showed gastric juice secretion-inhibitory and hypotensive activities ${ }^{145}$.

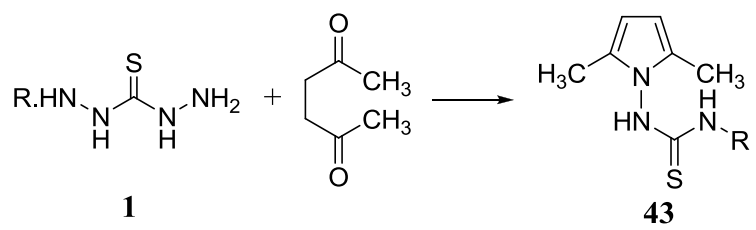

Reaction of thiocarbohydrazide 1 with representative unsaturated ketones led to the exclusive formation of monothiocarbohydrazones. The cytotoxicity of these compounds against murine P388 and L1210 cells, human T-lymphocytes, and human tumor cell lines was undertaken to ascertain their bioactivity, whereby the carbohydrazones would be predicted to be more than twice as cytotoxic as the ketones and Mannich bases from which they were derived. In general, conversion of the arylpentenones $44(\mathrm{R}=\mathrm{H})$ into corresponding biscarbohydrazones 45 was accompanied by a decrease of cytotoxicity. On the other hand, the compounds in series $45(\mathrm{R}=\mathrm{N}$-piperidylmethyl) were more potent cytotoxic agents than their corresponding precursors 44 . Some compounds displayed activity comparable with or exceeding that of melphalan ${ }^{146}$.<smiles>[R]c1ccc(/C=C/C(=O)CC([R])(C)C)cc1[R]</smiles>

44<smiles>[R]c1ccc(/C=C/C(=N/NC(=O)N/N=C(/C=C/c2ccc([R])c([R])c2)C([R])(C)C)C([R])(C)C)cc1[R]</smiles>

45

\subsection{Reaction with Dialkene Derivatives}

Condensation of thiocarbohydrazide 1 and di(2- formylphenoxy)ethylene 2-OHCC $\mathrm{H}_{4} \mathrm{OCH}_{2} \mathrm{CH}_{2} \mathrm{OC}_{6} \mathrm{H}_{4}-2-\mathrm{CHO}$ afforded (2:2) macrocyclic thiocarbohydrazone $46^{147}$.

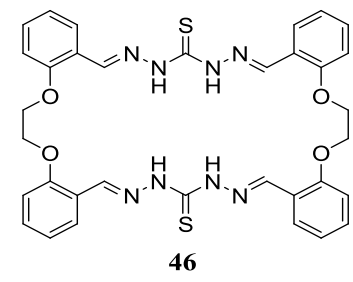

\subsection{Reaction with Amines and Amides}

The ion exchange resins with increased selectivity for copper are prepared by reaction of thiocarbohydrazide or hydrazothiocarbamide with epichlorohydrin and polyethylenepolyamines $^{148}$. Reaction of 3,3-dimethyl-2- oxobutanamide with thiocarbohydrazide 1 and MeI gaveamino (methylthio)triazinones $47\left(\mathrm{R}=1 \text {-methylcyclopropyl, } \mathrm{Me}_{3} \mathrm{C}\right)^{149}$.<smiles></smiles>

\subsection{Reaction with Hydrazones}

Reaction of thiocarbohydrazide 1 with $\mathrm{PhC}(\mathrm{OEt}): \mathrm{NH} . \mathrm{HCl}$ gave the thiocarbohydrazide derivative $\mathrm{PhC}$ (OEt) : $\mathrm{NNHCSNHNH}_{2} 48$, which cyclised to give tetrazinethione 49. Heating 49 in $(2 \mathrm{~N}) \mathrm{HCl}$ gave triazolethione $50(\mathrm{R}=$ $\left.\mathrm{NH}_{2}\right)^{150}$.

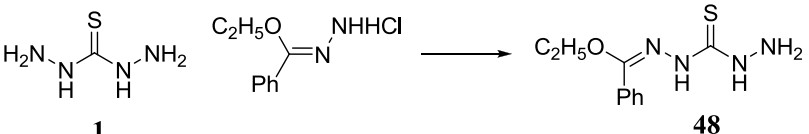

$$
\begin{aligned}
& 1
\end{aligned}
$$

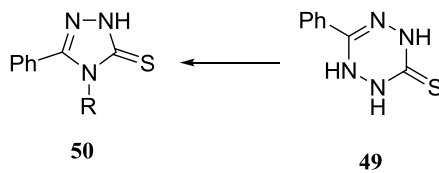

Using thiocarbohydrazide and thiosemicarbazides, 3amino-2-alkyl/arylimino-5-carbethoxy-thiazolidin-4-ones 51, 2-hydrazino-6-carbethoxy-4H,6H-1,3,4-thiadiazin-5-one 52, 5,7-disubstituted-4H-pyrazolo[5,4-e]1,3,4-thiadiazines 53 and 2-hydrazino-7-phenyl-4H-isoxazolo[5,4-e]-1,3,4thiadiazine 54 derivatives have been synthesized ${ }^{151}$.<smiles>[R]N=C1SC(C(=O)OCC)C(=O)N1N</smiles><smiles>CCOC(=O)C1SC(NN)=NNC1=O</smiles>

52<smiles>[X]C1=NN([X])c2[nH]ncc2S1</smiles>

$\mathrm{H}_{2} \mathrm{~N}-\mathrm{NH}$<smiles>CN1CC2=C(O1)N(c1ccccc1)N=CS2</smiles>

54

Synthesis of fused pyrimido[4,5-e]thiadiazines and novel 
spiro compounds such as 55, 56, and 57 and their precursors were reported $^{152}$.<smiles>[R]c1ccccc1N1C(=O)C2SC(NN)=NNC2N(c2ccccc2[R])C1=S</smiles><smiles>O=C1NC(=Nc2ccccc2)SC12NNC(=Nc1ccccc1)S2</smiles><smiles>NNC1=NNC(=O)C2(S1)S/C(=N\c1ccccc1)NC2=O</smiles>

\section{Conclusions}

The review covers recent literature regarding the synthesis and chemical reactions of thiocarbohydrazides. Thiocarbohydrazides are easily synthesized and are useful in the synthesis of highly functionalized heterocyclic compounds and used in the design of novel highly effective pharmaceuticals with a broad spectrum, besides their applications in several methods for metal ions determination and structural determination of cells and tissues.

\section{REFERENCES}

[1] Kelley, R. O.; Dekker, R. A. F.; Bluemink, J. G. J Ultrastructure Res. 1973, 45, 254-8.

[2] Huet, M.; Cantin, M. Montreal, Montreal, QC, Can. Laboratory Investigation 1974, 30, 514-24.

[3] Rambourg, A. Proc. Int. Symp., 2nd. 1974, Meeting Date 1973, 245-53.

[4] Yunge, L.; Ballak, M.; Beuzeron, J.; Lacasse, J.; Cantin, M. J Physiol Pharmacol. 1980, 58, 1463-76.

[5] Wallace, R. John. Appl. Environ. Microbiol. 1980, 39, 630-4.

[6] Mariani-Colombo, Paola; Vannini, G. L.; Mares, Donatella. Protoplasma 1980, 104, 105-17.

[7] Lefranc, G.; Chung, Y. T.; Barriere, P.; Pradal, G. Histochemistry 1980, 66, 277-84.

[8] Gros, D.; Challice, C. E. J. Histochem. Cytochem. 1975, 23, 727-44.

[9] Philippe, M.; Fournet, B.; Caigneaux, E.; Schrevel, J. Biologie Cellulaire (1977-1980), 1979, 35, 165-74.

[10] Pfueller, U.; Franz, H.; Bergmann, P.; Ziska, P. Supplementband 1980, 22 127-30.

[11] Hoch, H. C. Planta 1979, 147,186-95.
[12] Parmley, R. T.; Eguchi, M.; Spicer, S. S. J. Histochem. Cytochem. 1979, 27, 1167-70.

[13] Huet, M.; Benchimol, S.; Castonguay, Y.; Cantin, M. Histochemistry 1974, 41, 87-105.

[14] Sannes, P. L.; Eguchi, M.; Spicer, S. S. J. Histochem. Cytochem. 1979, 27, 1180-1.

[15] Sannes, P. L.; Eguchi, M.; Spicer, S. S. Laboratory Investigation 1979, 41, 135-43.

[16] Murata, F.; Yoshida, K.; Ohno, S.; Nagata, T. Histochemistry (1978), 58(1-2), 103-11.

[17] Sannes, P.; Spicer, S. S.; Katsuyama, T. J. Histochem. Cytochem. 1979, 27, 1108-11.

[18] Willingham, M. C.; Yamada, S. S.; Pastan, I. Proc. Natl. Acad. Sci. U. S. A. 1978, 75, 4359-63.

[19] Postma, D. S.; Logue, S.; Pecorak, J. B.; Prazma, J. Histochem. J. 1978, 10, 53-61.

[20] Poulain, D.; Tronchin, G.; Dubremetz, J. F.; Biguet, J. Annales de Microbiologie (Paris) 1978, 129A, 141-53.

[21] Lamb, J. M.; Berjak, P. Proceedings - Electron Microscopy Society of Southern Africa 1977, (7) 95-6.

[22] Blanchardie, P.; Carde, J. P.; Cassagne, C. Biologie Cellulaire (1977-1980) 1977, 30, 127-36.

[23] Postek, M. T.; Tucker, S. C. J. Microscopy (Oxford, United Kingdom) 1977, 110, 71-4.

[24] Schade, H. A. R. Acta Histochemica, Supplementband 1977, (18) $87-91$.

[25] Murata, F.; Momose, Y.; Nagata, T. Histochemistry 1977, 52, 307-16.

[26] Meier, H.; Reid, J. S. G. Planta 1977, 133, 243-8.

[27] Catesson, A. M. Journal de Microscopie (Paris) 1973, 16, 95-104.

[28] Reis, D.; Roland, J. C. Journal de Microscopie (Paris) 1975, 20, 271-84.

[29] Freundlich, A. Planta 1974, 118(1), 85-7.

[30] Hanker, J. S.; Thornburg, L. P.; Yates, P. E.; Moore, H. G. Histochemie 1973, 37, 223-42.

[31] Gavriliuc, Angela N.; Budeanu, Constantin H. Tehnologia si Chimia Produselor Alimentare 1978, (1) 83-8.

[32] Dixon, J. F. P.; O'Brien, R. L.; Parker, J. W. Sch. Med. Exp. Cell Res. 1975, 96, 383-7.

[33] Dixon, J. F. P.; Parker, J. W.; O'Brien, R. L. J. Immunol. 1976, $116,575-8$.

[34] Craig, A. S. Histochemistry 1974, 42, 141-4.

[35] Geyer, G. Acta Histochemica 1973, 47, 273-7.

[36] Wiles, D. M.; Suprunchuk, T. (Canadian Patents and Development Ltd.). U.S. 1973, 5 pp.

[37] Meldrum, B. S.; Horton, R. W.; Sawaya, M. C. B. J. Neurochem. 1975, 24, 1003-9.

[38] Ueda, H.; Fujimori, O. Anatomica Japonica 1995, 72, 109-17. 
[39] Ueda, T.; Fujimori, O.; Tsukise, A.; Yamada, K. Histochem. Cell Biol. 1998, 109, 399-407.

[40] Ueda, T.; Fujimori, O.; Yamada, K. J. Histochem. Cytochem. $1995,43,1045-51$

[41] Ueda, T.; Kajita, K.; Fujimori, O. Histochem. J. 1998, 30, 667-676.

[42] Levanon, D.; Stein, H. Unit of Electron Microscopy, Bruce Rappaport. Histochem. J. 1999, 31, 71-73

[43] Ge, Y.; Ohmori, J.; Tsuyama, S.; Yang, D.; Kato, K.; Miyauchi, M.; Murata, F. Cell Tissue Res. 1998, 293, 121-131.

[44] Yang, D.; Kasamo, H.; Miyauchi, M.; Tsuyama, S.; Murata, F. Histochem. J. 1996, 28, 33-43.

[45] Thomopoulos, G.N.; Garrett, J.R.; Proctor, G.B.; Hartley, R.; Zhang, X.S. Microscopy Res. Tech. 1996, 35, 365-376.

[46] Ueda, H.; Fujimori, O.; Abe, M. Arch. Histol. Cytol. 1996, 59, 389-397.

[47] Jauneau, A.; Quentin, M.; Driouich, A. Protoplasma 1997, 198, 9-19.

[48] Shibata, N. Connective Tissue 1995, 26, 307-16.

[49] Tokoh, C.; Takabe, K.; Fujita, M.; Saiki, H. Cellulose (Dordrecht, Netherlands) 1998, 5, 249-261.

[50] De Moraes B.C.; Meirelles, M.N.S.L.; Da Silva, A.M.M.; De Oliveira, P.C. Mycoses 1997, 40, 91-94.

[51] Neyrolles, O.; Brenner, C.; Prevost, M.; Fontaine, T.; Montagnier, L.; Blanchard, A. Microbiology (Reading, United Kingdom) 1998, 144, 1247-1255.

[52] Miyazaki, T.; Fujiki, T.; Inoue, Y.; Takano, K. Arch. Histol. Cytol. 1998, 61, 199-214.

[53] Iwano, M.; Fukui, K.; Takaichi, S.; Isogai, A. Chromosome Res. 1997, 5, 341-349.

[54] Chissoe, W.F.; Skvarla, J.J. Proceedings of the Oklahoma Academy of Science 1996, 76 83-85.

[55] Malinin, G.I.; Lo, H.K.; Malinin, T.I. Histochem. Cell Biol. 1998, 109, 1-10.

[56] Lubbering-Sommer, B.; Compere, P.; Goffinet, G. Tissue Cell 1996, 28, 621-630.

[57] Ohmori, J.; Nawa, Y.; Yang, D.; Tsuyama, S.; Murata, F. J. Histochem. Cytochem. 1999, 47, 481-488.

[58] Juranic, Z.; Anastasova, F.; Juranic, I.; Stanojkovic, T.; Radulovic, S.; Vuletic, N. J. Exp. Clin. Cancer Res. 1999, 18, 317-324.

[59] Sasaki, A.; Sakamoto, T. (Unitika Ltd., Japan). Jpn. Kokai Tokkyo Koho 1980, 4 pp.

[60] Sasaki, A.; Kamemaru, K.; Ono, Y. (Unitika Ltd., Japan). Jpn. Kokai Tokkyo Koho 1979, 8 pp.

[61] Sasaki, A.; Kamemaru, K.; Ono, Y. (Unitika Ltd., Japan). Jpn. Kokai Tokkyo Koho 1979, 7 pp.

[62] Sasaki, A.; Kamemaru, K.; Ono, Y. (Unitika Ltd., Japan). Jpn. Kokai Tokkyo Koho 1979, 10 pp.
[63] Sasaki, A.; Kamemaru, K. (Unitika Ltd., Japan). Jpn. Kokai Tokkyo Koho 1978, 7 pp.

[64] Sasaki, A.; Kamemaru, K.; Ono, Y. (Unitika Ltd., Japan). Jpn. Kokai Tokkyo Koho 1978, 11 pp.

[65] Joshi, S. R.; Srivastava, P. K.; Tandon, S. N. Sep. Sci. 1973, 8, 405-11.

[66] Joshi, S. R.; Srivastava, P. K.; Tandon, S. N. J. Radioanal. Chem. 1973, 13, 343-7.

[67] Pilipenko, A. T.; Arendaryuk, E. N. Kiev. Gos. Univ., Kiev, USSR. Ukrainskii Khimicheskii Zhurnal (Russian Edition) $1979,45,562-6$.

[68] Anon. UK. Research Disclosure 1977, 157, 54-6.

[69] Wernicke, Ubbo; Odenwaelder, Heinrich; Sommer, Friedhelm. (Agfa-Gevaert A.-G., Fed. Rep. Ger.). Eur. Pat. Appl.1979, 26 pp.

[70] Von Koenig, A.; Odenwalder, H.; Peters, M.; Pueschel, W. (Agfa-Gevaert A.-G., Fed. Rep. Ger.). U.S. 1979, 13 pp.

[71] Odenwaelder, H.; Wernicke, U. (Agfa-Gevaert A.-G., Fed. Rep. Ger.). Ger. Offen. 1978, 26 pp.

[72] Tanuma, T. (Asahi Glass Co Ltd, Japan). Jpn. Kokai Tokkyo Koho 1996, 6 pp.

[73] Tanuma, T. (Asahi Glass Co Ltd, Japan). Jpn. Kokai Tokkyo Koho 1995, 5 pp.

[74] Tanuma, T. (Asahi Glass Co. Ltd., Japan). Eur. Pat. Appl. 1995, $15 \mathrm{pp}$.

[75] Niles, E. T. (Dow Chemical Co., USA). U.S. 1975, 5 pp.

[76] Sun, X.; Liu, Y. Huaxue Gongcheng (Xi'an, China) 1999, 27(6), 41-43.

[77] Malone, J.R. (Mobay Chemical Corp., USA). U.S. 1979, 4 pp.

[78] Cramm, G.; Bloecher, K.H. (Bayer A.-G., Fed. Rep. Ger.). Ger. Offen. 1978, 13 pp.

[79] Levinta, L.; Dietrich, M.; 1979, 30(7), 682-5.

[80] Toth, A.; Rupp, H.D.; Meyer, G. (AKZO G.m.b.H., Fed. Rep. Ger.). Ger. Offen. 1975, 18 pp.

[81] Sivasankaran, K.; Rao, S.K.; Mithyantha, M.S.; Bhat, S.K.; Suresh, S. (Rallis India Limited, India). Indian 1998, 16 pp.

[82] Joshua, C. P.; Rajan, V. P. Australian Journal of Chemistry 1976, 29(5), 1051-8.

[83] Hassan, S. M.; Emam, H. A.; Abdelall, M. M. J. Chem. Res., Synopses 2000, (12), 544-545, 1301-1315.

[84] Eberhardt, U.; Depner, J.; Schaumann, J. (Ger. Dem. Rep.). Ger. (East) 1978, 9 pp.

[85] Tokarzewski, L.; Borek, J. Pol. Prace Naukowe Uniwersytetu Slaskiego w Katowicach 1972, (27) 129-33.

[86] Pissiotas, G.; Schwarze, W.; Klenk, H.; Leuchtenberger, W. Ger. Offen. 1979, 15 pp.

[87] Klenk, H.; Schwarze, W.; Leuchtenberger, W. Ger. Offen. 1979, 13 pp.

[88] Braeuniger, H.; Fokken, B.; Kristen, H.; Peseke, K. (Ger. Dem. Rep.). Ger. (East) 1975, 3 pp. 
[89] Jautelat, M.; Ley, K. (Bayer A.-G.). Ger. Offen. 1973, 13 pp.

[90] Postovskii, I. Ya.; Novikova, A. P.; Chechulina, L. A.; Sidorova, L. P. Khimiya Geterotsiklicheskikh Soedinenii 1976, (8), 1051-5.

[91] Tripathi, A.; Sinha, A.; Pandey, O. P.; Sengupta, S. K. Synthesis and Reactivity in Inorganic and Metal-Organic Chemistry 2000, 30(1), 139-155.

[92] Zabin, S.A.; Jejurkar, C.R. J. Polym. Mater. 1997, 14, 239-243.

[93] Liu, J.; Dong, Y.; Yu, X.; Shi, Q. Ningxia Daxue Xuebao, Ziran Kexueban 2000, 21, 244-246.

[94] Srivastava, T. N.; Agarwal, M. Chem. Indian J. Chem., Sect. A: Inorg., Bio-inorg., Phys., Theor. 1979, 17A, 613-15.

[95] Singh, B.; Singh, R.; Chaudhary, R. V.; Thakur, K. P. Indian J. Chem. 1973, 11, 174-7.

[96] Singh, R.; Srivastava, J.P.; Mishra, L.K. Chem. Indian J. Chem., Sect. A: Inorg., Bio-inorg., Phys., Theor. 1977, 15A, 805-8.

[97] Swami, M. P.; Jain, P. C.; Srivastava, A. K. Curr. Sci. 1973, 42, 199-200.

[98] Dwarakanath, K.; Sathyanarayana, D. N.; Volka, K. Bull. Soc. Chim. Belges 1978, 87, 667-75.

[99] Dwarakanath, K.; Sathyanarayana, D. N.; Volka, K. Bull. Soc. Chim. Belges 1978, 87, 677-83.

[100] Savel'eva, Z.A.; Larionov, S.V.; Nikolaev, A.V.; Nasonova, L.I.; Dolenko, G.N. Seriya Khimicheskikh Nauk 1977, (4), 73-8.

[101] Savel'eva, Z.A.; Larionov, S.V.; Nikolaev, A.V.; Kolomiets, T.I.; Shklyaev, A.A. Seriya Khimicheskikh Nauk 1973, (5), 69-75.

[102] Swami, M.P.; Jain, P.C.; Srivastava, A.K. Chem. Vijnana Parishad Anusandhan Patrika 1974, 17, 221-3.

[103] Bacchi, A.; Carcelli, M.; Pelagatti, P.; Pelizzi, C.; Pelizzi, G.; Zani, F. J. Inorg. Biochem. 1999, 75, 123-133.

[104] Verma, U.N. Asian Journal of Chemistry 1998, 10(3), 502-506.

[105] Jamgekar, D.S.; Angadi, S.D.; Kulkarni, V.H. Natl. Acad.Sci. Lett. (India) 1997, 20, 133-136.

[106] Kumari, P.; Mishra, L.K. J. Indian Chem. Soc.1995, 72(7), 463-5.

[107] Zabin, S.A.; Jejurkar, C.R. Asian J. Chem. 1995, 7, 542-50.

[108] Yu, X.; Liu, J.; Dong, Y. Lanzhou D. X., Ziran K. 2000, 36, 127-132.

[109] Cordero, M.T.S.; Alonso, E.I.V.; De Torres, A.G.; Pavon, J.M.C. J. Anal. At. Spectrom. 1996, 11, 107-10.

[110] Zougagh, M.; Rudner, P. C.; Garcia d. T., Amparo; C. Pavon, J. M. J. Anal. At. Spectrom. 2000, 15, 1589-1594.

[111] Hainberger, L.; De Luca Rebello, A. Mikrochimica Acta 1974, (5), 885-8.

[112] Pilipenko, A.T.; Arendaryuk, E.N. Ukrainskii Khimicheskii
Zhurnal (Russian Edition) 1977, 43(3), 273-7.

[113] Alonso, E.V.; Cordero, M.T.S.; Garcia, A.; Pavon, J.M.C. Fresenius' (What is Fresenius')? J. Anal. Chem. 1995, 351, 802-4.

[114] Collado, G.; Bosch, C.; Garcia, A.; Cano, J.M. Analusis 1995, 23, 224-7.

[115] Narayana, B.; Gajendragad, M. R.; Bhat, K. S. J. Indian Chem. Soc. 1998, 75, 112-113.

[116] Rudner, P. C.; Garcia, T.A.; Cano, P.J.M.; Rodriguez C.E. J. Anal. At. Spectrom. 1998, 13, 243-248.

[117] Sen, A.K.; Singh, R.N.; Handa, R.N.; Dubey, S.N.; Squattrito, P.J. J. Mol. Struct. 1998, 470(1-2), 61-69.

[118] Invidiata, F.P.; Furno, G.; Lampronti, I.; Simoni, D. J. Heterocycl. Chem. 1997, 34, 1255-1258.

[119] Invidiata, F.P.; Furno, G.; Simoni, D.; Lampronti, I.; Musiu, C.; Milia, C.; Scintu, F.; La Colla, P. Farmaco 1997, 52, 259-261.

[120] Quraishi, M.A.; Rawat, J.. Annali dell'Universita di Ferrara, Sezione 5: Chimica Pura ed Applicata, Supplemento 2000, 11(9th European Symposium on Corrosion Inhibitors 2000, (1), 493-506.

[121] Quraishi, M.A.; Rawat, J.; Ajmal, M. J. Electrochem. Soc. India 2000, 49, 35-39.

[122] Dickore, K.; Eue, L.; Schmidt, R. R. Ger. Offen. 1975, 30 pp.

[123] Belcher, L.K.A.; Squattrito, P.J. Book of Abstracts, 219th ACS National Meeting, San Francisco, CA, March 26-30, 2000 .

[124] El-Ashry, E.H.; Awad, L.F.. Book of Abstracts, 218th ACS National Meeting, New Orleans, Aug. 22-26 (1999).

[125] Yang, X.; Song, Z.; Tang, N.; Tan, M. Lanzhou D. X., Ziran Kexueban 1998, 34, 106-109.

[126] Yoshida, T.; Nomura, T. (Kanegafuchi Chemical Industry Co., Ltd., Japan). Jpn. Kokai Tokkyo Koho 1999, 9 pp.

[127] Holla, B.S.; Gonsalves, R.; Sarojini, B.K. Indian J. Chem., Sect. B: Org. Chem. Incl. Med. Chem. 1997, 36B, 943-946.

[128] Xu, P.; Sun, X.; Zhang, L.; Zhang, Z. China. J. Chem. Res., Synopses 1999, (2), 170-171.

[129] Jackman, D. E. Eur. Pat. Appl. 1980, 13 pp.

[130] Bogdanowicz, M. J. U. S. Publ. Pat. Appl. B 1976, 5 pp.

[131] Merz, W. (Bayer A.-G., Fed. Rep. Ger.). U.S. 1978, 7 pp.

[132] Larsen, S.D.; Vaillancourt, V.A.; May, P.D.; Tanis, S.P.; Tucker, J.A.; Meglasson, M.D.; Schostarez, H.J. (USA). U.S. 1999, 15 pp.

[133] Bailey, J. J. Chem. Soc., Perkin Trans. 1 1977, (18), 2047-52.

[134] Ammar, Y.A.; El-Gaby, M.S.A.; Zahran, M.A.; Abdel-Salam, A.A. Phosphorus, Sulfur Silicon Relat. Elem. 2000, (157) 87-95.

[135] Singh, P.; Singh, Archana; Chauhan, K. B. S. Orient. J. Chem. 1999, 15, 569-571. 
[136] Chattopadhyay, S. K.; Mak, T. C. W. Inorg. Chem. Commun. 2000, 3, 111-113.

[137] Islam, M.R.; Abedin, M.J.; Hossain, M.M.; Duddeck, H. J. Bangladesh Chem. Soc. 1998, 11, 71-78.

[138] Abdo, M.A.; Zeid, I.F.; El-Hiti, G.A.; Mahmoud, O.E. Indian J. Chem., Sect. B: Org. Chem. Incl. Med. Chem. 1999, 38B, 850-853.

[139] Awad, L.F.; El Ashry, S. Carbohydr. Res. 1998, 312, 9-22.

[140] Awad, L.F.; El Ashry, S.H. Nucleosides Nucleotides 1999, 18, 557-558.

[141] Ascher, G.; Reinshagen, H. (Sandoz Ltd., Switz.). Patentschrift (Switz.) 1976, 3 pp.

[142] Fedorova, O.V.; Popova, V.A. Zhurnal Obshchei Khimii 1995, 65, 657-61.

[143] Ren, Y.; Dai, R.; Wang, L.; Wu, J. Synthet. Commun. 1999, 29, 613-617.

[144] Tomchin, A.B.; Kharit, Y. A.; Kutsenko, A. K. 1973, 7, 10-13.
[145] Sato, T.; Tafusa, F.; Nakagawa, K. (Otsuka Pharmaceutical Co., Ltd., Japan). Jpn. Kokai Tokkyo Koho 1979, 5 pp.

[146] Dimmock, J.R.; Kumar, P.; Allen, T.M.; Kao, G.Y.; Halleran, S.; Balzarini, J. Pharmazie 1997, 52, 182-186.

[147] Zhang, H.; Xie, F. X.; Tian, Y. P.; Zhu, X. H.; Zhang, Y. H.; Duan, C.Y.; Ni, S.S. Chin. Chem. Lett. 1998, 9, 111-112.

[148] Samborskii, I.V.; Nekrasova, L.G.; Vakulenko, V.A.; Lipatova, L.N. (USSR). U.S.S.R. 1976.

[149] (Deutsche Gold- und Silber-Scheideanstalt vorm. Roessler, Fed. Rep. Ger.). Fr. Demande 1979, 11 pp.

[150] Postovskii, I. Ya.; Ershov, V. A.; Sidorov, E. O.; Serebryakova, N. V. Khimiya Geterotsiklicheskikh Soedinenii 1977, (11), 1564-8.

[151] Chande, M.S.; Pankhi, M.A.; Ambhaikar, S.B. Indian J. Chem., Sect. B: Org. Chem. Incl. Med. Chem. 2000, 39B, 603-609.

[152] Chande, M.S.; Pankhi, M.A.; Sugdare, V.V.; Ambhaikar, S.B. Indian J. Chem., Sect. B: Org. Chem. Incl. Med. Chem. 1999, 38B, 925-931. 